Table. Frequency of articular and entheseal involvement of different anatomical sites in PsA

\begin{tabular}{llll}
\hline $\begin{array}{l}\text { Upper extremities / } \\
\text { Joints / Entheses }\end{array}$ & Frequency & $\begin{array}{l}\text { Lower extremities / } \\
\text { Joints / Entheses }\end{array}$ & Frequency \\
\hline Infraspinatus & $5 / 912(0.5 \%)$ & $\begin{array}{l}\text { Patellar ligament } \\
\text {-Proximal }\end{array}$ & $19 / 2166(0.9 \%)$ \\
& & -Distal & $25 / 2166(1.2 \%)$ \\
Triceps brachii & $21 / 912(2.3 \%)$ & -Pes anserinus & $37 / 2166(1.7 \%)$ \\
Medial epicondyle & $21 / 912(2.3 \%)$ & Biceps femoris & $7 / 2280(0.3 \%)$ \\
Lateral epicondyle & $34 / 912(3.7 \%)$ & Semimembranosus & $35 / 2166(1.6 \%)$ \\
& & $\begin{array}{l}\text { Quadriceps femoris } \\
\text { Tibialis anterior }\end{array}$ & $52 / 2166(2.4 \%)$ \\
& & Tibialis posterior & $13 / 2166(0.4 \%)$ \\
& & Achille & $46 / 2166(2.1 \%)$ \\
& & Plantar fascia & $30 / 2166(1.4 \%)$ \\
\hline
\end{tabular}

There was difference between US synovitis detection of upper (57,1\%) and lower $(42,9 \%)$ extremities $(p=0.04)$. Total count of US enthesitis of lower extremities $(70,4 \%)$ was significantly higher than of the upper $(29,6 \%$; $<<0.01)$.

Conclusion: US synovitis of upper extremities was slightly higher than in lower. US enthesitis of lower extremities is significantly higher. US imaging can be used to diagnose enthesitis and synovitis, especially in patients in whom symptoms may be difficult to discern, and data on location of pathological lesions will be useful.

References:

[1] Perrotta FM, Astorri D, Zappia M, Reginelli A, Brunese L, Lubrano E. An ultrasonographic study of enthesis in early psoriatic arthritis patients naive to traditional and biologic DMARDs treatment. Rheumatollnt 2016;36:1579-83.

[2] Balint PV, Terslev L, Aegerter P et al. Reliability of a consensus-based ultrasound definition and scoring for enthesitis in spondyloarthritis and psoriatic arthritis: an OMERACT US initiative. Ann Rheum Dis.;2018;77(12):1730-1735.

Disclosure of Interests: None declared

DOI: 10.1136/annrheumdis-2020-eular.5900

\section{AB1092 ULTRASOUND EXAMINATION OF JOINTS AND PERIARTICULAR TISSUES IN PATIENTS WITH INFLAMMATORY BOWEL DISEASES.}

G. Gainullina ${ }^{1}$, E. Kirillova ${ }^{1}$, A. Odincova ${ }^{2}$, E. Belousova ${ }^{1}$, D. Abdulganieva ${ }^{1}$ ${ }^{1}$ Kazan State Medical University, Kazan, Russian Federation; ${ }^{2}$ Republican Clinical Hospital, Kazan, Russian Federation

Background: Joints and entheseal involvement is a common extraintestinal manifestation in inflammatory bowel diseases (IBD) [1]. Recent studies have shown the superiority of ultrasound over clinical findings in the evaluation of joints and periarticular tissues.

Objectives: To assess of joint and entheseal involvement in IBD patients using ultrasound with Power Doppler, their correlation with IBD clinical variables and the difference between Crohn's disease (CD) and ulcerative colitis (UC).

Methods: We prospectively included 38 IBD patients into the study. Disease activity was evaluated in CD by Harvey Bradshaw, in UC - Mayo Index. Peripheral joints and entheses were imaged by ultrasound, using Samsung Accuvix A30 5-13 MHz linear array transducer. Ultrasound examination of 14 peripheral joints (hip, knee, ankle, shoulder, acromioclavicular, elbow, wrist) and 35 entheses was performed. Vascularization on them was assessed with Power Doppler (PD). Entheseal abnormalities were scored with US according to indices GUESS, MASEl and BUSES [2]. Statistical analysis was done by Mann-Whitney test and Spearman criteria by "Statistica" software.

Results: In 38 patients UC was in 22 (58\%), CD - in $16(42 \%)$. The mean age of UC patients was $28(23 ; 35)$ years, in CD - $33(27 ; 36)$ years. The mean duration of UC was $24(10 ; 48)$ months; CD - $66(24 ; 114)$ months. The majority of patients had highly active disease: in UC - moderate and severe attacks in 16 pts (72\%), in CD out of 16 patients, moderate and severe activity was observed in $9(56 \%)$. Synovitis were found in 19 patients (50\%), 8 patients with UC (36\%), and 10 patients with $\mathrm{CD}(62 \%)$, synovitis with vascularization was detected in 7 patients $(18 \%)$, five with CD $(13 \%)$, two with UC $(9 \%)$.

Enthesitis (echogenicity reduction and thickening) was detected in 30 patients $(79 \%), 8(50 \%)$ pts with CD and $17(77 \%)$ pts with UC, enthesitis with vascularization (PD) in 13 pts $(34 \%), 5(31 \%)$ pts with $C D$ and $8(36 \%)$ pts with UC. Tenosynovitis was observed in 11 pts $(29 \%)$, three (19\%) with CD and $8(36 \%)$ pts - UC, tenosynovitis with vascularization in two patients $(5 \%)$, one with $\mathrm{UC}$ and one with $\mathrm{CD}$. Structure damage (erosion, enthesophytis) were found in 23 patients (61\%), 12 patients $(75 \%)$ with $C D$ and $11(50 \%)$ patients with UC.

There were no significant differences in ultrasound signs of joint and entheses damage between patients with $\mathrm{UC}$ and $\mathrm{CD}$.

We found an association between the clinical characteristics of IBD and the ultrasound signs of entheses damage: duration of the disease has a direct moderate correlation with the number of enthesitis $(S R=0.36 ; p=0.026)$ and GUESS (SR $=0.37 ; p=0.022$.

There was no statistically significant relationship between the severity of the attack and damage to the joints and entheses.

Conclusion: The severity of joint and periarticular tissues damage is significantly correlated with the duration of the index disease and are independent of IBD activity.

References:

[1] The First European Evidence-based Consensus on Extra-Intestinal Manifestations in IBD // JCC. - 2016. -V. 10, № 3. - P. 239-254.

[2] Bandinelli F, Milla M, Genise S et al. Ultrasound discloses entheseal involvement in inactive and low active inflammatory bowel disease without clinical signs and symptoms of spondyloarthropathy. Rheumatology (Oxford). 2011 Jul; 50 (7): 1275-1279.

Disclosure of Interests: None declared

DOI: 10.1136/annrheumdis-2020-eular.5391

\section{AB1093 INTEROBSERVER AGREEMENT IN MAGNETIC RESONANCE OF SACROILIAC JOINTS ABOUT ACTIVE SACROILIITIS}

A. C. Genç ${ }^{1}$, F. Turkoglu Genc ${ }^{1}$, A. B. Kara ${ }^{2}$, Z. Ozturk ${ }^{3}$, D. Karatas ${ }^{3}$

Ü. Erkorkmaz ${ }^{4}$, Y. Gunduz ${ }^{2}$, E. Gönüllü ${ }^{3}{ }^{1}$ Sakarya University, Internal Medicine, Sakarya, Turkey; ${ }^{2}$ Sakarya University, Radiology, Sakarya, Turkey; ${ }^{3}$ Sakarya University, Internal Medicine Rheumatology, Sakarya, Turkey; ${ }^{4}$ Sakarya University, Biostatistics, Sakarya, Turkey

Background: Axial spondyloarthritis has characteristic clinical features such as enthesitis, sacroilititis and spondylitis, and extra-articular manifestations(1). Magnetic resonance imaging (MRI) of sacroiliac (SI) joints is used to detect early sacroilitis(2). Health institutions in our country carry out some of the radiology reporting services by outsourcing for reasons such as high cost and insufficient number of radiologists(3).

Objectives: We decided to evaluate the interobserver agreement in active MR findings of SI between radiologist of outsourcing radiology services and local/ expert radiologist in musculoskeletal diseases.

Methods: Between the years of 2015 and 2019, 8100 sacroiliac MRIs were taken at our center. The MRI of 1150 patients who were reported as active or chronic sacroiliitis from these sacroiliac MRIs or whose MRI was considered by the primary physician in favor of sacroiliitis was included in the study. Concordance between Evaluation and Service Procurement was examined using Kappa $(k)$ coefficients. Mc Nemar test was used to compare the evaluation result between two observers. A p-value $<0.05$ was considered significant. Analyses were performed using commercial software (IBM SPSS Statistics, Version 23.0. Armonk NY: IBM Corp.)

Results: Of the 1150 patients examined in the study, 526 (45.7\%) were male and $624(54.3 \%)$ were female. The general average age is $37.20 \pm 11.65$ and the average age of men and women is $34.98 \pm 11.19$ and $39.07 \pm 11.71$ respectively. A statistically significant difference was found between the expert radiologists and outsourcing radiologist reports. In other words, a high level of compatibility was not found among the evaluators $(p<0.001)$. When the consistency between expert radiologist and outsourced radiologist reports was examined, it was observed that there was a medium level of concordance $(k=0.589)$.

Conclusion: The diagnosis of a spondyloarthropathy may be delayed for some reasons. In addition to the insidious course of the disease, being contented with an outsourced radiologist report may delay diagnosis. If the patient's clinic and MRI report are not consistent, the patient should not be removed from follow-up. References:

[1] Braun J. 'Axial spondyloarthritis including ankylosing spondylitis' Rheumatology (Oxford). 2018 1;57(suppl_6):vi1-vi3

[2] Jans L, Egund N, Eshed I, Sudoł-Szopińska I, Jurik AG. Sacroilititis in Axia Spondyloarthritis: Assessing Morphology and Activity. Semin Musculoskelet Radiol. 2018;22: 180-188.

[3] Quélin B, Duhamel F. Bringing Together Strategic Outsourcing and Corporate Strategy: European Management Journal. 2003. pp. 647-661. doi:10.1016/ s0263-2373(03)00113-0

OUTSOURCING

RADIOLOGIST REPORTS

NOT ACTIVE ACTIVE TOTAL $p$

SACROILIITIS SACROILITIS

\begin{tabular}{llcccc}
\hline EXPERT & NOT ACTIVE & 508 & 178 & 686 & \\
RADIOLOGIST & SACROILIITIS & & & & \\
REPORTS & ACTIVE & 59 & 405 & 464 & $<0.0010 .589$ \\
TOTAL & SACROILIITIS & 567 & 583 & 1150 &
\end{tabular}

